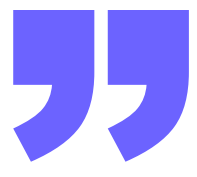

\title{
THE STUDY OF ANALYSIS CHARACTERIZATION IN "FIVE FEET APART" MOVIE BY JUSTIN BALDONI
}

\author{
Ni Putu Ayu Gita Maharani' ${ }^{1}$ I GB Wahyu Nugraha Putra ${ }^{2}$, \\ Ni Nyoman Deni Aryaningsih ${ }^{3}$ \\ Mahasaraswati Denpasar University, Indonesia ${ }^{123}$ \\ gitaxoxo34@gmail.com \\ wahyunugraha1980@yahoo.com \\ nymdeni@yahoo.com
}

\begin{tabular}{|c|c|}
\hline & ABSTRACT \\
\hline Journal History & $\begin{array}{l}\text { This study is focused on analyzing } \\
\text { characterization in "Five Feet Apart "movie by } \\
\text { Justin Baldoni. This study has two aims, namely 1) }\end{array}$ \\
\hline Submitted 28 th December 2021 & to find out the types of characterization and to \\
\hline Revised 21 th January 2022 & describe the main character in "Five Feet Apart" \\
\hline Accepted 23rd January 2022 & and 2) to find out the characterization of the main \\
\hline Published 24th January 2022 & $\begin{array}{l}\text { character realized in "Five Feet Apart" movie by } \\
\text { Justin Baldoni. The data were analyzed based on } \\
\text { the theory proposed by Kenney (1996) and Wellek }\end{array}$ \\
\hline & $\begin{array}{l}\text { and Warren (1962). The result of this analysis } \\
\text { showed that there were } 5 \text { types of characterization }\end{array}$ \\
\hline Keywords: & $\begin{array}{l}\text { from Kenney theory such as Discursive Method, } \\
\text { Dramatic Method, Character on other Character, }\end{array}$ \\
\hline $\begin{array}{r}\text { Character, Characterization, } \\
\text { Movie }\end{array}$ & $\begin{array}{l}\text { Mixing Method and Contextual Method and } 3 \\
\text { theory dimension characterization such as } \\
\text { Physiological Dimension, Sociological Dimension } \\
\text { and Psychological Dimension. }\end{array}$ \\
\hline
\end{tabular}




\section{INTRODUCTION}

Literature can be defined as creative art. It has important role in human life and has functioned to educate and entertain human (Cianciolo, 1982). Literature can be interpreted as a source or reference used in various activities in the world of education or other activities. Literature can also be interpreted as a reference used to obtain certain information. Literature can be in the form of books or various kinds of other writings such as poetry, prose, drama, biography, and essay. Many people today like literature because literature is a person's thoughts and is expressed in a writing. Many literary works are written in the form of a movie.

According to Brocket in Budiman (2012: 03), movie is one of the most objective arts, since characteristically it presents both outer and inner experience use speech and action. Movie or film is the oldest electronic media compared to other electronic media. The existence of a movie is phenomenal because it can show a live image on the screen. Since its appearance, films have been loved by people around the world. Even films have become an inseparable part of human life. Nowadays many people are interested in movies especially teenagers. And this study focused to analyses and learn about character and characterization.

Jones (1968) says that characterization is a literary device that is used step by step in literature to highlight and explain the details about a character in a story. It is in the initial stage where the writer introduces the character with noticeable emergence and then following the introduction of the character, the writer often talks about his behavior; Then as the story progress, the thought process of the character. A character is a person or someone in the story. Character is the distinctive values, both character, character, or personality of a person which is formed from the results of internalizing various policies that are believed and used as a way of viewing, thinking, acting, speaking, and behaving in everyday life. From the character that exists in humans, there are character values based on culture and nation such as religious, honest, tolerance, discipline, hard work, creativity, independence, democratic, curiosity, national spirit, love for the homeland, respect for achievement, friendly or communicative, peace-loving, likes to read, care about the environment, cares about social, and is responsible.

Characterization or disposition is a description of the character of the story. It can be about a physical picture gender, face, eyes, hair, clothes, age, how to walk, and so on. It can also be a mental picture and emotions. Characterization is an interesting topic to analyses because we learn about personality person. There are many benefits from analyzing this characterization because we can study the psychology of a person. The author interest with characterization because characterization is important 
in the movie. Characterization is hidden side of person and in characterization we learn about personality person and many other about physiological. And in this study chose Five Feet Apart as the data because this movie has complicated story and tells the true story of a patient with cystic fibrosis.

\section{METHODS}

In conducting this research, the researcher used qualitative method to analyze types of characterization. The writer used the theory of characterization from Kenney (1996), then supported by the theory proposed by Wellek and Warren (1962). In the theory mentions that there are 5 types of characterization, those are Discursive Method, Dramatic Method, Character on other characters, Mixing Method, and Contextual Method. Beside those 3 theories of characterization dimension from Wellek and Warren (1962) such as Physiological Dimension, Sociological Dimension, and Psychological Dimension also used to analyze the data. The data source of this research was taken from American romantic movie entitled "Five Feet Apart "movie by Justin Baldoni. This movie talks about two teenagers' patient's cystic fibrosis named Stella Grant and William Newman, they fall in love but they have to be hindered by five steps due to their illness which requires them to keep their distance. In analyzing the data, there are four steps to collecting the data that the researchers use in this research, there are: (1) Watching movie "Five Feet Apart "for several time. (2) Taking note, the dialogue from the main character. (3) Classifying the required data to answer the statements of the problems correctly related to theories. (4) Verifying the data that have been chosen to be included in chapter four which show the results of the study.

\section{RESULTS}

\section{RESULT AND DISCUSSION}

In this research, the researcher used the qualitative method to presents the data of analysis. The findings are divided into two parts, namely, the first to show the types of characterization from the main character and the second to show the characterization dimension from the main character. The researchers used a table to find this data.

\section{DISCUSSION}

In this research, there are 5 types of characters such as Discursive Method, Dramatic Method, Character on Other Characters, Contextual Method and Mixing Method. And characterization dimensions such as Physiological Dimensions, Sociological dimensions, psychological dimensions. Based on this analysis the writer found only 6 data the first 2 data from Dramatic Method,2 data from Character on other Characters, 1 Contextual Method, and 1 data from characterization dimensions such as Physiological Dimension. The data from this analysis found in the "Five 
Feet Apart "movie by Justin Baldoni. There are three main characters from this movie named Stella Grant, William Newman, and Poe ramies. The characterization of Stella Grant is brave, kind and for her psychological, she is a beautiful girl with curly hair. And William Newman is a melancholy and cool person and his psychological is handsome with messy hair. Last Poe ramies he is the best friend of Stella Grant he is a funny and kind person and his psychological he has a pale face and white skin. Below there are two tables to analyses the data:

\subsection{Types of Characterization}

Table 1. Types of Characterization Occur

\begin{tabular}{l|lll} 
No & \multicolumn{2}{l}{ Types of Characterization } & Occurrence \\
\hline 1 & Dramatic Method & 2 \\
2 & Character on Others & 2 \\
3 & Characters & 1 \\
& \multicolumn{2}{l}{ Contextual Method } &
\end{tabular}

Based on this table, there are 5 types of characterizations but in this study the writer found 3 characterizations, there are 2 Character on other characters, 2 Dramatic method,1 Contextual method. And the writer couldn't find 2 types characterization specifically Discursive Method and Mixing Method.

\subsection{Types of Dimension Characterization}

Table 2. Types of Characterization Dimension

\begin{tabular}{|c|c|c|c|}
\hline $\begin{array}{l}\text { Name of } \\
\text { Main } \\
\text { Character }\end{array}$ & $\begin{array}{l}\text { Physiological } \\
\text { Dimension }\end{array}$ & $\begin{array}{l}\text { Sociological } \\
\text { Dimension }\end{array}$ & $\begin{array}{l}\text { Psychological } \\
\text { Dimension }\end{array}$ \\
\hline $\begin{array}{l}\text { Stella } \\
\text { Grant }\end{array}$ & $\begin{array}{l}\text { Beautiful } \\
\text { Curly hair }\end{array}$ & $\begin{array}{c}\text { Patients' } \\
\text { Cystic } \\
\text { fibrosis }\end{array}$ & $\begin{array}{l}\text { Brave } \\
\text { Kind }\end{array}$ \\
\hline $\begin{array}{l}\text { William } \\
\text { Newman }\end{array}$ & $\begin{array}{l}\text { Handsome } \\
\text { Messy hair }\end{array}$ & $\begin{array}{c}\text { Patients' } \\
\text { Cystic } \\
\text { fibrosis } \\
\text { Stella loved }\end{array}$ & $\begin{array}{l}\text { Patients' } \\
\text { Cystic fibrosis } \\
\text { Stella loved }\end{array}$ \\
\hline Poe Ramies & $\begin{array}{c}\text { Pale face } \\
\text { White skin }\end{array}$ & $\begin{array}{l}\text { Patient's } \\
\text { Cystic } \\
\text { fibrosis }\end{array}$ & $\begin{array}{l}\text { Funny } \\
\text { Kind }\end{array}$ \\
\hline
\end{tabular}


Based on this table the writer found dimension characterization by the main character in "Five Feet Apart" movie. There is characterization of Stella Grant, William Newman, Poe Ramies as the main character in Five Feet Apart movie by Justin Baldoni. But the writer only found 1 types dimensions characterization from Stella Grant specifically Physiological Dimension.

\section{Data 1}

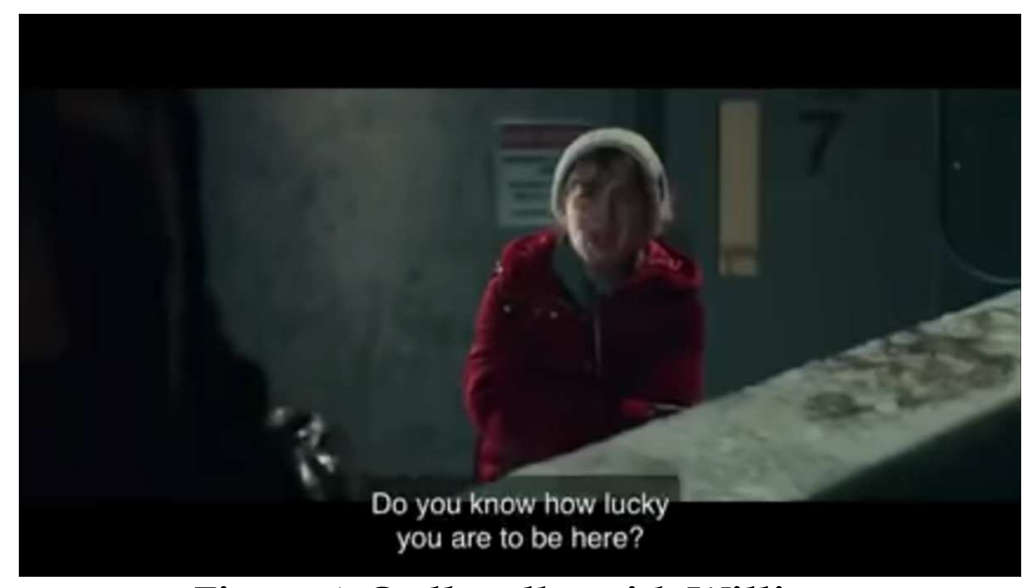

Figure 1. Stella talks with William

Setting: At outside hospital

Durations: (M.17:26 -M.17:38)

Conversations:

Stella : What are you doing? Do you have a death wish or something?

William : Hey! my lungs are toast, okay? can you just let me enjoy this view while I can?

\section{Stella: Do you know how lucky you are to be here?}

The dramatic method is a method of showing rather than telling. In the dramatic method, the author allows the character to reveal themselves to us 12 through their own words and action. The advantages of dramatic method could be obvious. If the dramatic method is compared to the discursive method, it is more lifelike and invites the readers' active for their participation in the theory.

The picture above is a type of dramatic method. there is seen Stella talking to William, at that time Stella thought that William would kill himself even though William wanted to enjoy his time. Based on dialogue Stella said, "Do you know how lucky you are to be here?" Stella said that William was very lucky with his current condition even though he was sick, but he was still given life. Stella said with a 
panicked face and with a worried expression on her face that made it dramatic.

\section{Data 2}

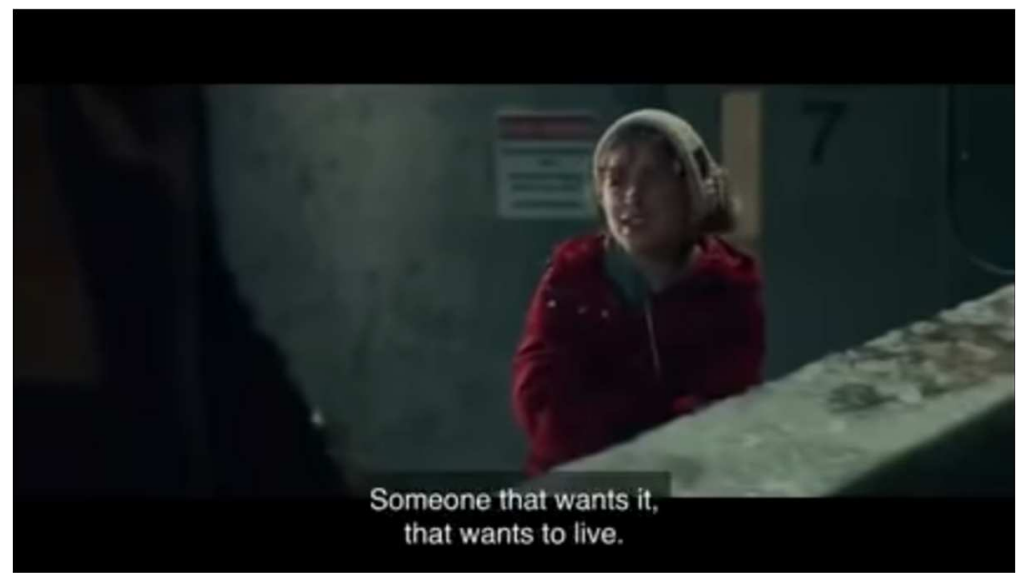

Figure 2. Stella talked with William

Setting: Outside hospital

Durations: (M.17:44 - M.17:57)

Conversations:

William : How do you know about my drug trial? You been asking about me?

Stella : Ugh! if you don't care, then leave. Give you spot to someone else.

\section{Someone that wants it wants to live.}

The Dramatic Method This method has its disadvantages, that is: it is less economical than the discursive since to show taking longer rather than telling. While the dramatic method encourages the active participation of the reader, it also increases the possibility of the reader's misjudging to the character.

This picture above is a type dramatic method. There Stella talking with William, at that time Stella was still talking to William. the conversation William asked how Stella found out about her treatment. Stella answered with a worried and annoyed face and she said, "Someone that wants it wants to live." That means if William violates his treatment, it's better if he gives his life to someone else because there are still many who want life. In this scene, the atmosphere is made a little dramatic because of the words spoken by Stella but William is indifferent and ignorant, so it makes this atmosphere a little fun. 


\section{Data 3}

Setting: At Hospital

Durations: (M. 59:57 - M. 59.59)

Conversations:

William : He cut and run when I was born. I guess having a sick kid wasn't part of this plan.

Stella : What about your mom?

William: She's beautiful and driven and smart

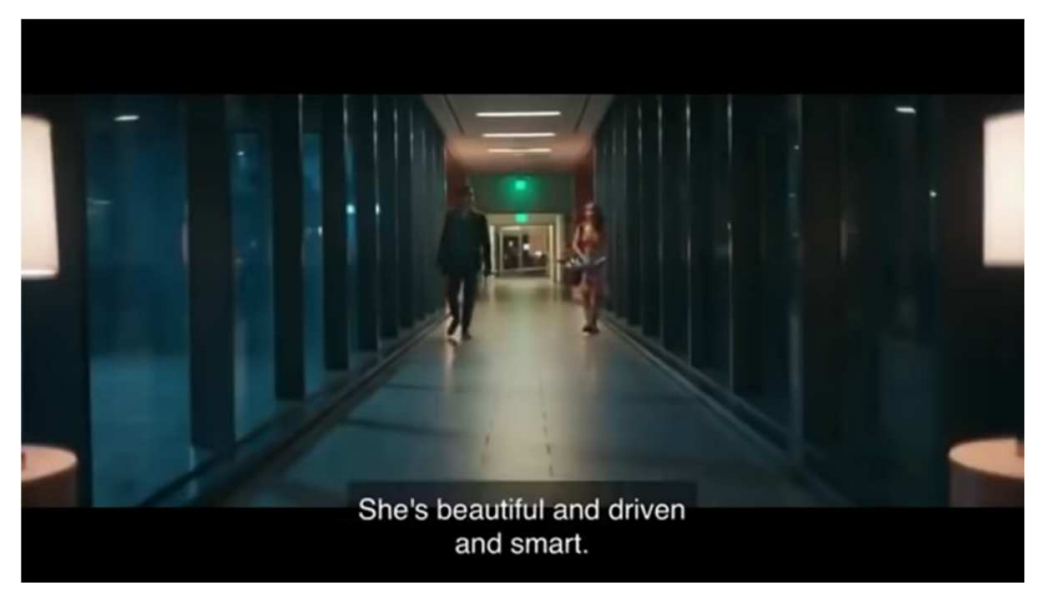

Figure 3. William talks about his mom.

Character on other characters means one-character talks about another character in a story. However, the reader must remember that this type of information which received is not reliable necessarily, because what A says about B may probably tell us more about A than B in the story.

Based on this data there are types of Character on other Characters. In this scene Stella and William first date then, William talks about his mother characteristic. From his dialogue "She's beautiful and driven and smart." he told Stella his very beautiful, smart, and driven mother. and William also said his mother was very focused on his treatment. At that time, they both wanted to date, and they looked happy.

\section{Data 4}

Setting: At Pool Hospital

Durations: (M.1: 01:30 - M. 1:01-35)

Conversations:

\section{William: What happened with Abby?}

Stella : She was cliffing diving in California. She landed wrong, broke her neck and drowned. They said didn't feel any pain, but how would they know if she felt pain? I was supposed to be there with her, but I got sick. Like always 
do I just keep imagining it over and over again. What she feeling. (Sobs) Without knowing that, she just never stops dying.

William : Stella, even if you were there, you still wouldn't know.

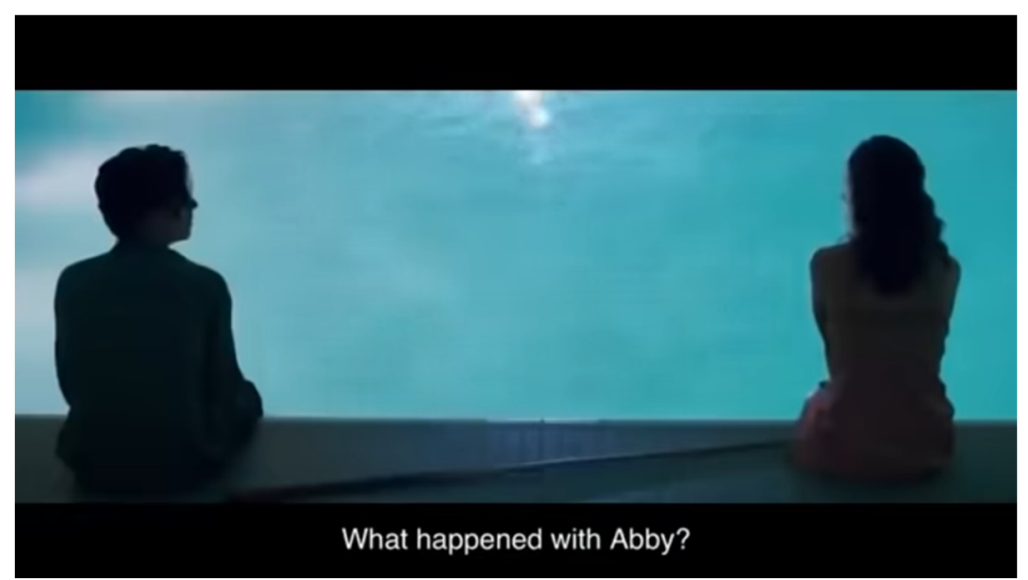

Figure 4. William asks about Abby

Based on this data their types are of Character on Other Characters. In the scene William and Stella in Hospital pool they were on a date. At the time, William inquired about Abby, Stella's deceased sister. Abby died after cliff diving and breaking her neck, according to Stella. Stella felt terrible about not being there for Abby while she needed her. Stella also lost contact with the one who was always by her side.

\section{Data 5}

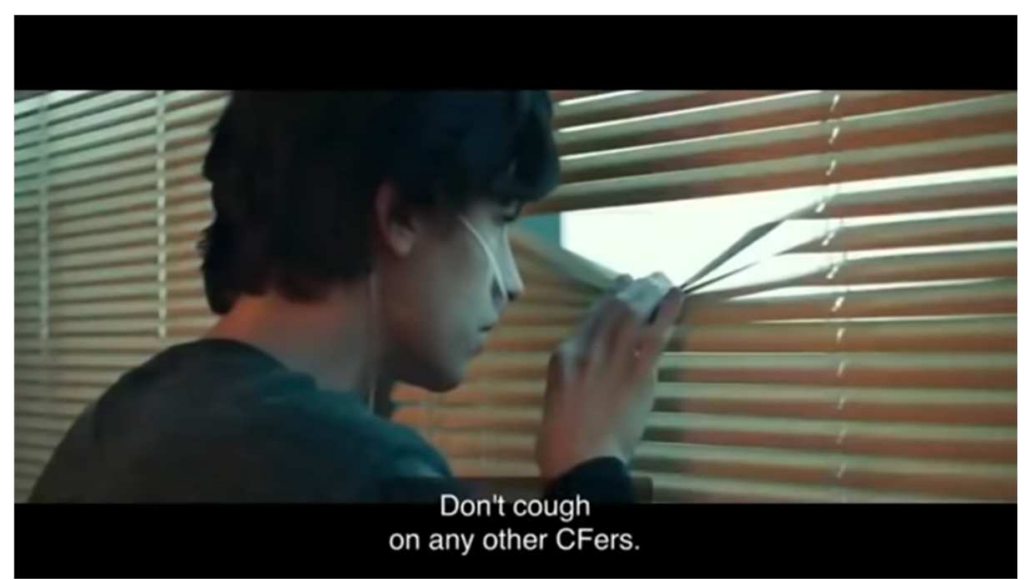

Figure 5. When William talks about his pain

By the point of view of contextual method, it could mean the device of suggesting character by the verbal context which surrounds the character. It could be explained specifically that a character is described 
constantly in terms appropriate to a beast of prey, the reader may conclude that the author is trying to tell him or her something.

Based on the picture above, this is the type of data Contextual Method. at that time Dr. Hamid spoke about William's illness to his mother and William. Dr. Hamid explained that Phase one clinical trials only started 18 months ago, so we had to be patient and William needed to help us with that. The risk of cross-infection will be higher now. and William immediately interrupted Dr. Hamid's remarks that he should not be near other CFers. in other words, William knew what Dr. Hamid meant by himself.

\section{Data 6}

Setting: At Pool Hospital

Durations:(M 1:07:17)

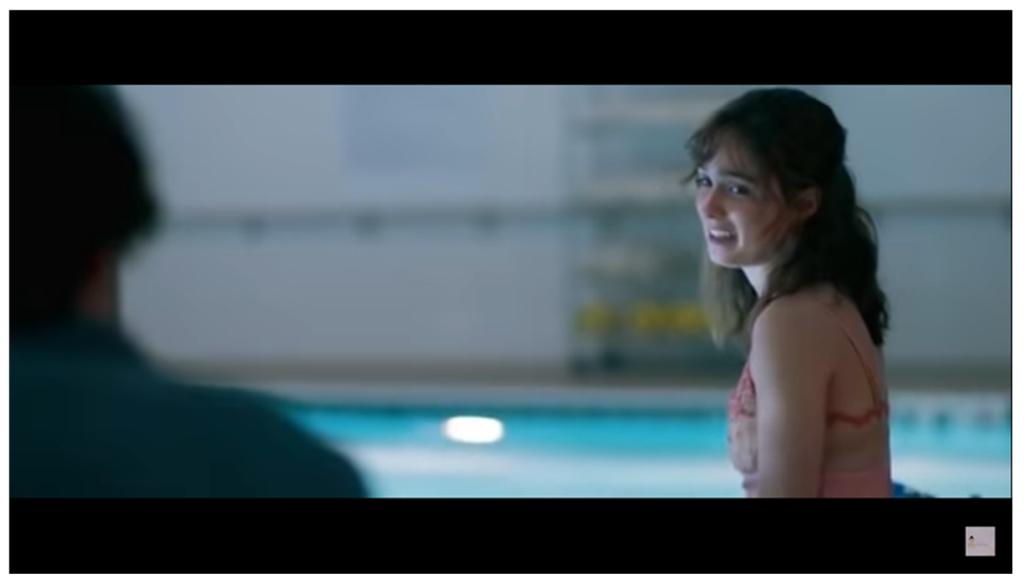

Figure 6. Appearance of Stella

Physiological Dimension is the study of human or specifically human appearance. Physiological dimension is simply concerned with the aspect of physical description such as sex, height/weight, skin, eyes, hair color and other physical appearance. Another element in the stricter of character is the physiological dimension, which is observable though sex, age, physical appearance such shape of body, whether or not a person is handsome or beautiful, color of skin and hair.

Based on this picture, this is a type of dimension characterization that is Physiological Dimension. In this picture, this is the Appearance of Stella who is a beautiful girl with curly hair. At that time Stella was with William by the hospital swimming pool. they dated secretly and spent time together. they exchanged stories about their lives. This scene is a romantic one and a bit dramatic and the audience feels a different sensation. 


\section{CONCLUSION}

Based on the data analyzed in "Five Feet Apart "movie by Justin Baldoni. Using the theory proposed by William Kenney (1996) for the problem it was found all types of characterization proposed by William Kenney (1996), three categories are found, they are Dramatic Method, Character on Other Characters and Contextual Method. Dramatic Method is showing the personality main character, Character on Other Characters talks about another character in this movie and Contextual Method show about hidden feeling main character. In this study the writer only found 6 data and written on the table. 5 from theory characterization based on Kenney such as 2 Dramatic Method,2 Character on other Characters, 1 Contextual Method. And from Wellek and Warren the writer only found 1 data Physiological Dimension from Stella Grant. The conclusion is intended to answer the research problems or purposes. It helps the readers understand why your research should matter to them after they have finished reading the paper. It is not just a summary of the main topics covered or a re-statement of your research problem, but a synthesis of key points and, if applicable, where you recommend new areas for future research.

\section{REFERENCES}

Graham, G. 2005. Philosophy Of the Art. 3rd.Ed. New York: Routledge

Guntur. Mahardika. 2016. Psychological Analysis of Main and Secondary Character in Movie Hangover by Todd Philips E -Jurnal Humanis, Fakultas Sastra dan Budaya Unud

https://ocs.unud.ac.id/index.php/sastra/article/view/19383/12852 Kenney, William. 1966. How to Analyze Fiction. USA: Monarch Press.

Melsiana, Handayani. 2020. The Analysis of Main Character Characterization in Safe Haven Movie by Lasse Hallstrom, Denpasar: STIBA Saraswati Denpasar

Surya. Pramana. 2019. The Analysis of Main Character Development and Characterization in The Fate and Furious, Denpasar: STIBA Saraswati Denpasar

Wellek, Rene and Austin, Warren. (1949)" “Theory of Literature”. New york : Harcout Brace \& World.

Sastrawan, I. G. A. Ajus Benny. 2006. The Analysis of Character in J. K Rowling's "Harry Potter and The Half-Blood Prince". Denpasar: Faculty of Letters Udayana Univercity.

PJ Ciancolo. 1982, from https:/ / www.jstor.org 